\title{
The Influence of Social Economic Status and Parenting Patterns through Par- ent Interaction of Speaking Skills of Children Aged 5-6 Years Old
}

\author{
Hj. Yusida *, Aslamiah, Sulaiman \\ Master Program of Teacher Education for Early Childhood Education, Universitas Lambung Mangkurat, \\ Banjarmasin 70123, Indonesia
}

Article history:

Submission September 2020

Revised November 2020

Accepted November 2020

${ }^{*}$ Corresponding author:

E-mail: jah_yusida60@gmail.com

\begin{abstract}
This study aims to analyze and describe the influence of socioeconomic status and parenting styles through parent interactions on children's speaking skills. The research sample was 213 parents and children using a simple random sampling technique. This research is important because speaking skills are a communication tool and a source of information for children. Data processing was carried out through the help of a computer program IBM SPSS version 22.0, hypothesis testing using path analysis. The results showed: There is a direct effect (1) socioeconomic status on parental interactions. (2) Parenting patterns of parental interactions. (3) Socio-economic status of children's speaking skills. (4) The pattern of caring for children's speaking skills. (5) Parents' interaction with children's speaking skills. There is no indirect effect (6) Socio-economic status through parental interaction on anal speaking skills. (7) Parenting patterns through parent interactions with children's speaking skills. So, it can be concluded that socioeconomic status, parenting patterns, and parental interactions affect children's speaking skills.
\end{abstract}

Keywords: Children's speaking skills, socio-economic status, parenting pattern, parent interaction

\section{Introduction}

Early childhood is a child who has an age of 0 - 6 years. Children at this time readily accept stimuli. So, at this time children need to receive stimuli from the surrounding environment. Educational institutions are one of the environments that are close to children, in this case, Early Childhood Education (PAUD). It is because important to lay the foundation for later development in early childhood (Boyden, Dawes, Dornan, \& Tredoux, 2019). During this time, children become the common basis for all dimensions of sustainable development (Thematic Group 4 Sustainable Development Solutions, 2014).

Early childhood education is a coaching effort aimed at children from birth to six years of age, carried out by providing educational stimuli to help children's growth and development so that they are ready to enter further education (Metroyadi, 2017). By providing education during early childhood, children can also start learning about identities in the early years of their life (Marpinjun, Rengganis, Riyanto, \& Dhamayanti, 2018). It can be done by providing the pre-kindergarten school as a program for early childhood education (Bartik, 2014).

Early childhood education, especially kindergarten, aims to provide experience, experience becomes the basis for growth and efforts to stimulate children's growth following their respective potential and needs (Suriansyah, Landasan Pendidikan, 2011). Experience is understood in its traditional philosophical meaning as a subjective apprehension of reality 
(Oksala, 2014). It is also argued that experience is a term of psychological growth (Rehmke, 1897). Experiences including events, behaviors, feelings, or thoughts at the moment of, or close to, their occurrence, and within the context of a person's everyday life (Riediger, 2010). Moral facts can only be ascertained by experience which can be varying for each individual (Gwynn, 1923). That is why, early childhood education should be observed and documented to understand them better (Cowan \& Felwitt, 2020) in experiencing everyday life.

According to (Permendikbud, 2014) six aspects need to be developed in early childhood. The six aspects are moral and religious values, cognitive, physical motor, language, socialemotional, and art. From several aspects of early childhood development, one important aspect to be developed is the aspect of language development. Through this aspect, children can express what is on their minds, can express their opinions, and children can socialize with fellow humans in the surrounding environment. Language has a very important role in human life, namely as a social means (Purwanti et al., 2018). Language indeed has an important role in society(Luck, 2020). With the proficiency of the language, a human can get things done (Hardison, et al., 2012) by communicating which is basically what society has been built from language skills have four aspects of skills, namely listening, speaking, reading, and writing skills. Of the four aspects of these skills, the focus of this study is speaking skills. According to (Wigayuwiva, 2014) speaking skills are skills that need to be learned for early childhood as a means of communicating with other people. Meanwhile, communication is an activity carried out by everyone everywhere(Suriansyah, 2014).

According to Denis McQuail communication can be defined as information transmission, ritual through which humans express meanings and participate in society, the creation of attention and publicity, and reception that requires the encoding and decoding of meanings (Fuchs, Communication and Society, 2020a). While, the dialogue is to serve as the presumed natural form of communication (De Vries, 2012) and

JK6EM | Journal of K6 Education and Management communication is a form of teleological positing that aims at reproducing social relations (Fuchs, 2020b).

Based on observations at the Kindergarten Gugus Melati, Central Banjarmasin District in October 2017, it was found that some children still had difficulty talking to them. When asked questions about their own identity, the child also experienced difficulties, such as mentioning the name of the parents, place, and date of birth, and nature of the residence. Children may have trouble talking as they are still trying to master their spoken language (Guitar, 2006). However, it is normal since almost everyone has these common experiences from time to time (Bennett, 2006). Without realizing it, children have developed the skills for communication in infancy (Panico, Daniels, \& Claflin, 2011). Those skills are then nurtured and supported through the interactions with family and other caregivers (Johnston, 2005). Hence, to look at the children's difficulty of talking, the family is one of the significant factors.

The factors that influence language development are health, intelligence, family socioeconomic status, gender, family relationships, desire to communicate, encouragement, family size, birth order, and child training methods (Usman, 2015). The role of teachers and parents is very important in children's development, especially in the golden age of children (Safitri, Ahmad, \& Saleh, 2018; Dalle \& Mutalib, 2010). Based on these factors, the researchers limited the factors originating from the family, namely socioeconomic status, parenting (child training methods), and parental interactions (family relationships).

The family is the fundamental unit of society as it is the foundation for all the more complex arrangements humanity has managed to devise since the beginning of the historical era (Eberstadt, 2019). Families are responsible for providing funds for children's educational needs. Families with high socioeconomic conditions will experience less difficulty in fulfilling children's educational needs, in contrast to parents with low socioeconomic conditions. In line with this, a family that has a good socio-economic status will be able to provide good conditions for children's language development, besides that good family education also affects 
a person's language potential (Djamarah, 2011). This is what happened in China under the rapid socioeconomic transformations that have taken place there over the past several decades, the Chinese family households and the elderly living arrangements have changed (Yi \& Zhenglian, 2019). The status of socio-economic can be seen in many aspects. The socio-economic status in this study was seen from education, occupation, income, ownership of valuables, and social position.

The socio-economic conditions of parents can cause differences in children's speech. Children from groups with high socioeconomic conditions learn to speak more easily because they are more encouraged to talk and more guided to do so. Another condition that also causes differences in children's speech is children's training methods, or in this case parenting. Children who are trained with authoritarianism will experience obstacles in learning to speak (Kemendikbud, 2013). Hence, these adults are the people responsible for raising and creating them during their "tender age" (Reinhartz, 2020). At this age, children need both adequate knowledge, as well as a good character to prepare them for adult life (Altalib, Abu Sulayman, \& Altalib, 2013a) but it is better with no dictatorship.

Parenting is the relationship between parents and children in educating, guiding, disciplining, and protecting children to become disciplined following existing norms (Latifah, Wahyu, \& Metroyadi, 2019). Good parenting is a long-term investment and is the key to great success in the emotional, psychological, and physical development of children (Altalib, Abu Sulayman, \& Altalib, 2013b) that can be achieved through various styles. The parenting style in this study is permissive parenting, authoritarian, and democratic.

The development of speaking skills requires the participation of parents at home, so parents need to provide a stimulus that can develop speaking skills, such as when parents ask questions about children's activities that are carried out for a full day and answers from children. This will encourage children to express their thoughts and feelings. Therefore, there should be good interactions between parents and children. This is reinforced by the results of research by Nurlaeli (2015)which show that there is a significant relationship between parental interactions and children's speaking skills. Besides, parents need to be involved in child development because their sensitive responsiveness is crucial to secure attachment and its multiple consequences (Aboud, 2007). Thus, positive parenting practices, such as being emotionally supportive and providing a stimulating learning environment with language-rich interactions and opportunities to explore and discover, have immediate and lasting effects on children's academic, social, and emotional development (Auger et al., 2016).

Based on the problems that arise and some of the factors above, the researchers conducted a study to determine how much influence these factors have on children's speaking skills in Kindergarten Gugus Melati, Central Banjarmasin District.

\section{Material and Methods}

This research uses a quantitative descriptive approach. This study is intended to obtain an overview of how socioeconomic status, parenting, and parental interactions affect children's speaking skills (Figure 1).

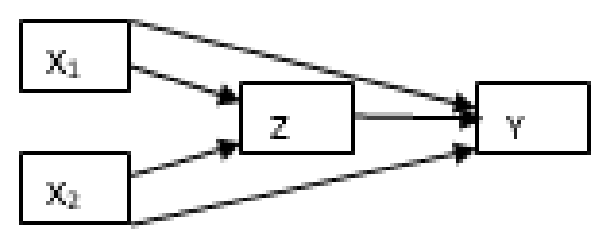

Figure 1. Influence diagram between variables X1, $\mathrm{X} 2, \mathrm{Z}$, and $\mathrm{Y}$
Information:
$\mathrm{X} 1$ = Socio-economic status
$\mathrm{X} 2=$ Parenting Pattern
$\mathrm{Z}=$ Parent Interaction
$\mathrm{Y}=$ Children's Speaking Skills

The population in this study amounted to 457 parents and children in TK Gugus Melati, Central Banjarmasin District, which was held in 
January - February 2020. Simple in this research was obtained using random sampling techniques, amounting to 213 parents and children. Data collection using questionnaires and observation. The questionnaire was filled in by the parents, while the observation sheet was filled in by the teacher. Meanwhile, the data analysis used to test the hypothesis is path analysis.

\section{Results and Discussion}

The results of descriptive statistical analysis of respondents to research variables (Table $1,2,3,4)$.

Table 1. Frequency distribution of socio-economic status

\begin{tabular}{ccc}
\hline Category & Frequency & Presentation \\
\hline Low & 1 & $0.5 \%$ \\
Moderate & 90 & $42.25 \%$ \\
High & 117 & $54.92 \%$ \\
Very high & 5 & $2.32 \%$ \\
Total & $\mathbf{2 1 3}$ & $\mathbf{1 0 0 . 0 \%}$ \\
\hline
\end{tabular}

Table 2. Frequency distribution of parenting pattern

\begin{tabular}{ccc}
\hline Category & Frequency & Presentation \\
\hline Not good & 25 & $11.75 \%$ \\
Pretty good & 59 & $27.70 \%$ \\
Well & 125 & $58.68 \%$ \\
Very good & 4 & $1.87 \%$ \\
Total & $\mathbf{2 1 3}$ & $\mathbf{1 0 0 . 0 \%}$ \\
\hline
\end{tabular}

Table 3. Frequency distribution of parent interaction

\begin{tabular}{ccc}
\hline Category & Frequency & Presentation \\
\hline Not good & 0 & $0 \%$ \\
Pretty good & 20 & $9,40 \%$ \\
Well & 75 & $35,2 \%$ \\
Ery good & 118 & $55,40 \%$ \\
Total & $\mathbf{2 1 3}$ & $\mathbf{1 0 0 , 0} \%$ \\
\hline
\end{tabular}

Table 4. Frequency distribution of children's speaking skills

\begin{tabular}{ccc}
\hline Category & Frequency & Presentation \\
\hline Undeveloped & 7 & $3.29 \%$ \\
Start developing & & \\
\hline
\end{tabular}


Develop as expected

Very well developed

Total
82

80

44
$38.50 \%$

$37.55 \%$

$20.66 \%$

$100.0 \%$

In the next step, the path results with multiple regression tests for each equation with the structure model I and structure model II are obtained. The summary in table 5,6,7:

Table 5 Summary of path analysis results

\begin{tabular}{|c|c|c|c|c|}
\hline \multicolumn{5}{|c|}{$\begin{array}{c}\text { Structure Model I } \\
\text { Socioeconomic status, Parenting pattern on } \mathrm{I}\end{array}$} \\
\hline Variable & Coefficient of Path & $T$ & $P$ & $R^{2}$ \\
\hline Socio economic & & & & 0.157 \\
\hline status & 0.252 & 3.920 & 0.000 & \\
\hline Parenting pattern & 0.267 & 4.163 & 0.000 & \\
\hline \multicolumn{5}{|c|}{$\begin{array}{c}\text { Structure Model II } \\
\text { Socioeconomic status, Parenting pattern, Parent interactions on Children's speaking } \\
\text { skills }\end{array}$} \\
\hline Variable & Coefficient of Path & $T$ & $P$ & $R^{2}$ \\
\hline $\begin{array}{c}\text { Socioeconomic } \\
\text { status } \\
\text { Parenting pattern } \\
\text { Parent interactions }\end{array}$ & $\begin{array}{l}0.126 \\
0.392 \\
0.146\end{array}$ & $\begin{array}{l}2.015 \\
6.300 \\
2.252\end{array}$ & $\begin{array}{l}0.045 \\
0.000 \\
0.025\end{array}$ & 0.258 \\
\hline
\end{tabular}

Table 6 Summary of decisions on testing hypotheses $\mathrm{H}_{01}, \mathrm{H}_{02}, \mathrm{H}_{03}, \mathrm{H}_{04}$ and $\mathrm{H}_{05}$

\begin{tabular}{|c|c|c|c|}
\hline & Hypotheses & $P$ & Decisions \\
\hline $\mathrm{H}_{01}$ & $\begin{array}{l}\text { There is no direct influence of } \\
\text { socioeconomic status on parental } \\
\text { interactions }\end{array}$ & 0.000 & Rejected \\
\hline $\mathrm{H}_{\mathrm{o} 2}$ & $\begin{array}{l}\text { There is no direct influence of parenting } \\
\text { pattern on parental interactions }\end{array}$ & 0.000 & Rejected \\
\hline $\mathrm{H}_{03}$ & $\begin{array}{l}\text { There is no direct influence of } \\
\text { socioeconomic status on children's } \\
\text { speaking skills }\end{array}$ & 0.045 & Rejected \\
\hline $\mathrm{H}_{04}$ & $\begin{array}{l}\text { There is no direct influence of parenting } \\
\text { pattern on children's speaking skills }\end{array}$ & 0.000 & Rejected \\
\hline $\mathrm{H}_{05}$ & $\begin{array}{l}\text { There is no direct influence of parental } \\
\text { interactions on children's speaking skills }\end{array}$ & 0.025 & Rejected \\
\hline
\end{tabular}

Table 7. Summary of decisions on testing hypotheses $\mathrm{H}_{06}$ and $\mathrm{H}_{07}$ 
H Yusida, 2020 / The influence of socal economic status and parenting pattern through parent interaction

\begin{tabular}{llccc}
\hline \multicolumn{1}{c}{ Hypotheses } & \multicolumn{2}{c}{$\begin{array}{c}\text { Coefficient of } \\
\text { Decisions Relations }\end{array}$} & Decisions \\
\cline { 2 - 4 } & & Direct & Indirect & \\
\hline $\mathrm{H}_{06}$ & $\begin{array}{l}\text { There is no indirect effect of } \\
\text { socioeconomic status through parental } \\
\text { interactions on children's speaking skills }\end{array}$ & 0.126 & 0.036 & Not Rejected \\
\hline $\mathrm{H}_{07}$ & $\begin{array}{l}\text { There is no indirect effect of parenting } \\
\text { pattern through parental interactions on } \\
\text { children's speaking skills }\end{array}$ & 0.369 & 0.038 & Not Rejected \\
\hline
\end{tabular}

Descriptive analysis in tables 1 - 4 to the hypothesis answer. First, the socioeconomic status of parents in TK Gugus Melati, Central Banjarmasin District with low criteria of 1 person $(0.5 \%)$, moderate criteria amounted to 90 people $(42.25 \%)$, high criteria amounted to 117 people (54.92\%), and very high criteria amounted to 5 people $(2.34 \%)$. So, that it is known that the socioeconomic status of the family at most is high.

Second, the parenting style in Gugus Melati Kindergarten, Central Banjarmasin District with unfavorable criteria was 25 people (11.75\%), 59 people $(27.70 \%)$ good enough criteria, 125 good criteria (58.68\%), and very good criteria amounted to 4 people $(1.87 \%)$. So that it is known that the most parenting styles are in good criteria. Third, the interaction of parents in TK Gugus Melati, Central Banjarmasin District with unfavorable criteria was 0 people $(0 \%), 20$ people $(9.40 \%)$ were good enough, good criteria were 75 people $(35.2 \%)$, and Very good criteria amounted to 118 people (55.40\%). So, it is known that most parent interactions are very good. Fourth, the children's speaking skills in Gugus Melati Kindergarten, Central Banjarmasin District with undeveloped criteria totaled 7 people (3.29\%), the criteria began to develop amounted to 82 people (38.50\%), the criteria for developing according to expectations were 80 people (37.55 \%), and very well developed criteria amounted to 44 people (20.66\%). So, it is known that most children's speaking skills are starting to develop.

There is a direct influence on socioeconomic status and parental interactions

This study found that there was a significant influence between socioeconomic status (X1) on parental interaction (Z) at TK Gugus
Melati, Central Banjarmasin District, this indicates that the results of the research on the null hypothesis ( $\mathrm{HO}$ ) were rejected so that the alternative hypothesis (Ha) was accepted.

One of the important factors in family life is socio-economic conditions, which affect the mental and physical life of individuals in the family. The socioeconomic status of the parents is the status that the parents have in society which can be seen from the level of education, type of work, income or income, the social position of the parents, and their valuables.

According to Gunarsa \& Gunarsa (2000) the amount of income earned by the family is related to the final education of parents affecting the interaction in the family. The existence of a family condition that has a high-income level also causes parents to treat children with more appreciation and praise. Also, the level of education of parents, either directly or indirectly, will affect communication between parents and children in the family environment. In line with this, the social status of the family has a significant influence on the behavior of children with their parents, especially the father in earning a living. If the social status of the child's family is the same as that of peers seen from the income level of the parents, the child will feel proud of their parents. If the child knows the lower family status, then the child feels ashamed and feels inferior, so he is very critical of his parents (Putri, Suriansyah, \& Wahdini, 2019).

Based on research data, it was also found that even though parents were busy working, parents still took the time to interact with their children after work. This research is in line with research(Baiti, Metroyadi, \& Wahyu, 2019)that there is a significant positive relationship between the family economy through 
parental communication on children's language skills.

\section{There is a direct influence on parenting styles and parental interactions}

This study found that there was a significant effect of parenting (X2) on parental interaction (Z) in TK Gugus Melati, Central Banjarmasin District, this indicates that the results of the research on the null hypothesis ( $\mathrm{H0}$ ) were rejected so that the alternative hypothesis $(\mathrm{Ha})$ was accepted.

In Gunarsa's view, parenting is a picture used by parents to nurture (care for, care for, educate) children. Meanwhile, according to Toha, parenting is the best way that parents can take in educating children as a manifestation and sense of responsibility towards children (Tridhonanto \& Agency, 2014).

Parenting style is the attitude or behavior of parents in caring for, caring for, educating, and guiding when interacting with children. The parenting style applied by parents to children will affect the interactions that occur between parents and children. The link between the two is very clear. In the care of parents towards their children, of course there will be interactions that occur such as communicating, chatting, and so on. In it, it can also be seen that based on the parenting patterns that are applied, the parenting styles that tend to be democratic, the interactions that occur are those that are full of love, openness, and have warm education.

This research is in line with research (Baiti, Metroyadi, \& Wahyu, 2019) that there is a significant positive relationship between parenting through parental communication on children's language skills.

\section{There is a direct influence on children's soci- oeconomic status and speaking skills}

This study found that there was a significant effect of socioeconomic status (X1) on children's speaking skills (y) in TK Gugus Melati, Central Banjarmasin District, this indicates that the results of the research on the null hypothesis (H0) were rejected so that the alternative hypothesis (Ha) was accepted.
Several studies on the relationship between language development and family socioeconomic status show that children who come from poor families' experience slower language development compared to children who come from better families. This results in differences in intelligence or learning opportunities for children from poor families compared to children from well-off families (Yusuf, 2004). This is in line with what Usman stated that one of the factors that influence children's language development is the socioeconomic status of the family (Usman, 2015). This study is in line with previous studies which showed that there was a significant positive relationship between the scores for the interaction between parents and children's language. Socioeconomic status has been proven to be a significant factor in children's language (Safitri, Ahmad, \& Saleh, 2018).

\section{There is a direct influence on children's par- enting patterns and speaking skills}

This study states that there is a significant effect of parenting (X2) on children's speaking skills (y) in TK Gugus Melati, Central Banjarmasin District, this shows that the null hypothesis (H0) is rejected and the alternative hypothesis (Ha) is accepted.

Parenting is a pattern of interaction between parents and children, regarding how, attitudes, or behavior of parents when interacting with children, including how parents apply rules, teach norms and provide attention and affection. Types of parenting include democratic, authoritarian, and permissive parenting (Madyawati, 2017).

Parenting patterns affect children's speaking skills, factors that influence children's communication are health, intelligence, family socioeconomic conditions, birth order, child training methods, multiple births, peer relationships, and personality (Kemendikbud, 2013) right will result in delays in children's language development.

Delays in language development cause children to experience obstacles in understanding conversations that occur between children of their age. Furthermore, this will become an obstacle for the child to express his will and resistance. Thus, language difficulties 
experienced by children make it difficult for children to communicate with others (Suriansyah \& Aslamiah, 2011). This study is in line with the results of research conducted by Restiyani, which is that there is a strong relationship between parenting and children's speech development (Restiyani, Lestari, \& Halida, 2013).

\section{There is a direct influence on the interaction of parents and children's speaking skills}

This study states that there is a significant effect of parental interaction (Z) on children's speaking skills (y) in TK Gugus Melati, Central Banjarmasin District, this indicates that the null hypothesis ( $\mathrm{HO}$ ) is rejected and the alternative hypothesis (Ha) is accepted.

The behavior of parents can influence the formation of children. A good relationship in the family between father, mother, and children in addition to family members can be well established if communication goes well in the family environment (Kunarti, 2004).

The interactions carried out by parents and children are more of reciprocal socialization. Reciprocal socialization is the socialization that takes place in two directions, namely socialization carried out by two people, such as socialization between mother and child or parent and child.

Speaking skills are activities to interact with the surrounding environment, both peers and older people, and become a means that can be used to express desires to others because the interactions between parents and children are two-way interactions. The better the interaction between parents and children, of course, the more it will provide a good stimulus for the development of children's speaking skills. Language development is one of the basic abilities that everyone must have (Purwanti \& Fathimah 2019). The first place to facilitate language development in children is the family. The family environment is the closest place to the child, namely the child's parents. Language development in children cannot be separated from the role and stimulus given by parents to their children (Sumaryanti, 2017) or parents are expected to be able to help and support children through guidance, direction, motivation, and other educational actions that are in line with the education program carried out by the school (Maimunah, Aslamiah, \& Suriansyah, 2018).

It is because motivation is essential to improve students' achievement (Dalle et al., 2017). Good interaction between parents and children can be seen from several characteristics, one of which is the attention of parents to children's needs. Psychological needs, namely the attention of parents to children in learning (Rizalie \& Aslamiah, 2015).

Based on the results of this study, parents rarely read fairy tales before going to bed, this is evidenced by the low score of the sub variable no.14, which is about reading fairy tales before bed. The sub-variables of interaction are also categorized as quite well done by parents, namely getting used to being directly involved when the child is playing with friends, not doing various activities while talking with children, buying CDs about stories or songs for children. When the parents are tired, the parents ignore the child's story and the parents just keep quiet when the child is watching their favorite movie, so the interaction effect coefficient score on speaking skills is very low.

\section{There is not indirect effect on socio-economic status through parental interaction on chil- dren's speaking skills}

This study states that there is no indirect influence on socioeconomic status (X1) through parental interaction $(\mathrm{Z})$ on children's speaking skills (y) in TK Gugus Melati, Central Banjarmasin District, this shows that the null hypothesis ( $\mathrm{HO}$ ) is not rejected and the alternative hypothesis $(\mathrm{Ha})$ is rejected.

The results of this study indicate that there is no indirect effect of socioeconomic status (X1) through parental interaction (Zz) on ana's speaking skills $(\mathrm{y})$ because from the calculation the value of the direct effect is greater than the indirect effect so that the socioeconomic status through interaction Parents have no significant effect on children's speaking skills. This is because of the influence of parental interaction (Z) on children's literacy skills (y)) has a very low coefficient of influence so that parental interaction $(\mathrm{z})$ cannot be an intermediary variable between socioeconomic status (X1) and children's speaking skills (y). Socioeconomic 
status affects children's speaking skills, and if parental interaction is used as an intermediary variable, parent interaction cannot increase or decrease the influence of socioeconomic status on speaking skills.

\section{There is an indirect effect of parenting pat- terns through parents' interaction on chil- dren's speaking skills}

This study states that there is no indirect effect of parenting (X2) through parental interaction (Z) on children's speaking skills (y) in TK Gugus Melati, Central Banjarmasin District, this shows that the null hypothesis ( $\mathrm{H} 0)$ is not rejected and the hypothesis alternative $(\mathrm{Ha})$ is rejected.

The results of this study indicate that there is no indirect effect of parenting (X2) through parental interaction $(\mathrm{Z})$ on children's speaking skills (y) because from the results of the calculation of the value that the direct effect is greater than the indirect effect so that parenting through human interaction ta on children's speaking skills does not have a significant effect. This is because the influence of parental interaction (Z) on children's speaking skills (y) the coefficient of influence is very low so that parent interaction (Z) cannot be an intermediary variable between foster care (X2) and children's speaking skills (y). Parenting affects children's speaking skills, and if parent interaction is used as an intermediary variable, parent interaction cannot increase or decrease the influence of parenting on children's speaking skills.

\section{Conclusion and Recommendation}

Based on the research results from data analysis and discussion, it is concluded that there is a direct influence on the following points in TK Gugus Melati, Central Banjarmasin District (1) Socio-Economic Status on Parental Interaction (2) Parenting Patterns on Parental Interaction (3) Social Status Economics of Children's Speaking Skills (4) Parenting Patterns of Children's Speaking Skills (5) Parents' Interaction with Children's Speaking Skills. There is no indirect effect (6) Socio-Economic Status through Parental Interaction on Children's Speaking Skills (7) Parenting Patterns through
Parental Interaction on Children's Speaking Skills.

Also, based on the results of the research and the conclusions drawn from this study, it is suggested that the Education Office, teachers, and parents strengthen cooperation in developing aspects of language development, especially speaking skills. Then parents are advised to be able to spend time interacting with children, giving freedom to children to express their thoughts and desires so that children dare to express their opinions and easily communicate with others.

\section{Acknowledgment}

We would like to acknowledge your support in writing this journal article. The author is assisted by many parties, especially the principal, teachers, and parents of children at TK Gugus Melati, Central Banjarmasin District.

\section{References}

Aboud, F. (2007). Evaluation of an Early Childhood Parenting Programme in Rural Bangladesh. Journal of Health, Population and Nutrition, 25(1), 3-13.

Altalib, H., Abu Sulayman, A., \& Altalib, O. (2013b). Good Parenting: What is it and How do We Begin? In ParentChild Relations: A Guide to Raising Children (pp. 3-22). London; Washington: International Institute of Islamic Thought.

Altalib, H., Abu Sulayman, A., \& Altalib, O. (2013a). Teaching Responsibility. In Parent-Child Relations: A Guide to Raising Children (pp. 357-369). London; Washington: International Institute of Islamic Thought.

Auger, A., Stevens, C., Cannon, J., \& Sontag-Padilla, L. (2016). Parenting Programs in Shelby County, Tennessee: A Brief Review of the Research Literature. In Parenting Programs in Shelby County, Tennessee: A Brief Review of the Research Literature (pp. 1-20). RAND Corporation.

Baiti, N., Metroyadi, \& Wahyu. (2019). Parenting Pattern and Socioeconomic Status through Parents Communication on Early Childhood Language Ability. Journal of K6, Education, and Manangement, 2(1), 62 - 63.

Bartik, T. (2014). A Proposed Early Childhood Education Strategy. In From Preschool to Prosperity: The Economic Payoff to Early Childhood Education (pp. 61-72). Kalamazoo, Michigan: W.E. Upjohn Institute.

Bennett, E. M. (2006). Working with People Who Stutter: A Lifespan Approach. Upper Saddle River, NJ: Pearson. 
Boyden, J., Dawes, A., Dornan, P., \& Tredoux, C. (2019). Early childhood: The essential foundation. In Tracing the Consequences of Child Poverty: Evidence from the Young Lives study in Ethiopia, India, Peru and Vietnam (pp. 49-72). Bristol, UK; Chicago, IL, USA: Bristol University Press.

Cowan, K., \& Felwitt, R. (2020). Towards valuing children's signs of learning. In C. C. (Eds.), Transforming Early Childhood in England: Towards a Democratic Education (pp. 119-133). London: UCL Press.

De Vries, I. (2012). Communication ideals, communication woes. In Tantalisingly Close: An Archaeology of Communication Desires in Discourses of Mobile Wireless Media (pp. 57-84). Amsterdam: Amsterdam University Press.

Djamarah, S. (2011). Psikologi Belajar. Jakarta: Rineka Cipta.

Eberstadt, N. (2019). China's Changing Family Structure: Dimensions and Implications (pp. 1-22, Rep.). American Enterprise Institute.

Fuchs, C. (2020a). Communication and society. In communication and capitalism: A critical theory (pp. 69-108). London: University of Westminster Press.

Fuchs, C. (2020b). Conclusion: advancing a dialectical, humanist, critical theory of communication and society. In Communication and Capitalism: A Critical Theory (pp. 353370). London: University of Westminster Press.

Guitar, B. (2006). Stuttering: an integrated approach to its nature and treatment. Baltimore, MD: Lipincott, Williams, \& Wilkins.

Gunarsa, S., \& Gunarsa, N. (2000). Psikologi perkembangan anak dan remaja. Jakarta: PT. Gunung Mulia.

Gwynn, S. (1923). Experience. The North American Review, 217(809), 502-509.

Hardison, C., Miller, L., Li, J., Schroeder, A., Burkhauser, S., Robson, S., \& Lai, D. (2012). Background on adult language learning. In second-language skills for all?: Analyzing a proposed language requirement for U.S. Air Force Officers (pp. 5-16). RAND Corporation.

Johnston, J. (2005). Factors that influence language development. Encyclopedia on Early Childhood Development, eds. R.R. Tremblay, R.G. Barr, \& R.deV. Peters, , 1-6.

Kemendikbud. (2013). Komunikasi dalam pengasuhan. Jakarta: Kemendikbud Direktorat Jenderal PAUD.

Kunarti. (2004). Pengaruh interaksi keluarga dan tekanan ekonomi terhadap kenakalan remaja di Sekolah Menengah Kejuruan Teknik Industru (SMK-TI). skripsi. Bogor: Program Sarjana. Institut Pertanian Bogor.

Latifah, Wahyu, \& Metroyadi. (2019). The Influence of Education, Employment and Care for the Independence of Children. Journal of K6, Education, and Management, 2(1), 9.

Luck, C. (2020). Linguistics and literature. In Rewriting Language: How Literary Texts Can Promote Inclusive Language Use (pp. 14-52). London: UCL Press.
Madyawati, L. (2017). Strategi pengembangan bahasa pada anak. Jakarta: Kencana.

Maimunah, Aslamiah, \& Suriansyah, A. (2018). The Integration of Sentra-Based Learning and Involment Of Family Program At Early Childhood In Developing Character Building (Multi Case At PAUD Mawaddah and PAUD alam berbasis karakter sayang ibu Banjarmasin, Indonesia . European Journal of Education Studies, 5(7), 53.

Marpinjun, S., Rengganis, N., Riyanto, Y., \& Dhamayanti, F. (2018). Feminists' strategic role in early childhood education. In Rosen R. \& Twamley K. (Eds.), Feminism and the Politics of Childhood: Friends or Foes? (pp. 218-224 ). London: UCL Press.

Metroyadi. (2017). Upaya mengembangkan aspek nilai-nilai agama dan moral (menirukan gerakan ibadah sholat) melalui model picture and picture dan simulasi pada kelompok A TK Insan Azkia Banjarmasin. Jurnal Pendidikan Prasekolah, 1(1), 8.

Nurlaeli, D. (2015). Correlation Between Parent's Interaction with the Conversation Skills of Aged 4 - 6 Years Children in TK Pertiwi of Babakan Kalimanah Purbalingga Jawa Tengah. Jurnal Pendidikan Guru Pendidikan Anak Usia Dini, 14.

Oksala, J. (2014). In defense of experience. Hypatia, 29(2), 388403.

Panico, J., Daniels, D., \& Claflin, M. (2011). Working in the Classroom with Young Children Who Stutter. YC Young Children, 66(3), 91-95.

Permendikbud. (2014). No. 137 tahun 2014 pasal 10.

Purwanti, R., \& Fathimah. (2019). Pengenalan aspek bahasa (bahasa inggris) untuk anak usia dini melalui nyanyian. Prosiding seminar nasional PS2DMP ULM, 5(2), 137.

Purwanti, R., Suriansyah, A., Aslamiah, \& Dalle, J. (2018). Introducing Language Aspect (English) to Early Childhood through The Combination of Picture and Picture Model, Talking Stick Model, Flashcard Media, and Movement and Song Method in BI Group at Matahariku Bilingual Kindergarten Landasan Ulin Tengah. European Jurnal of Education Studies, 5(7), 27.

Putri, H., Suriansyah, A., \& Wahdini, E. (2019). Effect Education and Income Levels and Parenting Patterns on Children's Social Behaviour. Journal of K6, Education, and Management, 2(2), 98.

Rehmke, J. (1897). Experience. he Philosophical Review, 6(6), 608-625.

Reinhartz, A. (2020). Parents and children: A philonic perspective. In Cohen S. (Ed.), The Jewish Family in Antiquity (pp. 61-88). Providence, RI: Brown Judaic Studies.

Restiyani, Lestari, S., \& Halida. (2013). Hubungan pola asuh dengan perkembangan bicara anak usia 4 - 5 tahun di TK 
Al-Falah Mempawah. Jurnal Pendidikan dan Pembelajaran Khatulistiwa, 2(2), 1-10.

Riediger, M. (2010). Experience sampling. In German Data Forum (RatSWD) , Building on Progress: Expanding the Research Infrastructure for the Social, Economic, and Behavioral Sciences (pp. 581-594). Opladen; Farmington Hills: Verlag Barbara Budrich.

Rizalie, A., \& Aslamiah. (2015). Kajian tentang kepedulian orang tua terhadap proses pendidikan di sekolah dasar (kajian komparasi pada Sekolah Dasar Negeri dan Sekolah Dasar Swasta di Kota Banjarbaru Kalimantan Selatan . Jurnal Paradigma, 10(1), 8.

Safitri, M., Ahmad, K., \& Saleh, M. (2018). Development of child independence through model picture and picture, examples non examples model and practical metgod directly activities of learning practical life in Group B Kasih Ibu Kindergarten, Banjarmasin, Indonesia. European Journal of Education Studies, 5( 7), 77.

Safwat, R., \& Sheikhany, A. (2014). Effect of parent interaction on language development in childreen. The Egyptian Journal of Otolaryngology, 255.

Sumaryanti, L. (2017). Peran lingkungan terhadap perkembangan bahasa anak. MUADDIB Jurnal Studi Kependidikan dan Keislaman, 84 - 85.

Suriansyah, A. (2011). Landasan pendidikan. Banjarmasin: Comdes.
Suriansyah, A. (2014). The relationship between school culture, communication, and commitment and the state elementary school teacher's performance. Cakrawala Pendidikan 33 (3), 359.

Suriansyah, A., \& Aslamiah. (2011). Strategi pembelajaran anak usia dini. Banjarmasin: Comdes.

Thematic Group 4 Sustainable development solutions. (2014). he Future of Our Children: Lifelong, Multi-Generational Learning For Sustainable Development (pp. 39-57, Rep.). Sustainable Development Solutions Network.

Tridhonanto, A., \& Agency, B. (2014). Mengembangkan pola asuh demokratis. Jakarta: PT Elex Media Komputindo.

Usman. (2015). Perkembangan bahasa dalam bermain dan permainan: Untuk pendidikan anak usia dini. Yogyakarta: Deepublish.

Wigayuwiva. (2014). Meningkatkan keterampilan berbicara anak usia dini melalui media gambar berseri di kelompok B3 Taman Kanak-Kanak Pertiwi 1. Retrieved from http://repository.unib.ac.id/8719

Yi, Z., \& Zhenglian, W. (2019). China's changing family structure: dimensions and implications (pp. 79-101, Rep.) (Eberstadt $N$., Ed.). American Enterprise Institute.

Yusuf, S. (2004). Psikologi perkembangan anak dan remaja. Bandung: PT. Remaja Rosdakarya. 